УДК 338.432:631.1

DOI: https://doi.org/10.32782/2224-6282/159-19

\author{
Новицька I. В. \\ аспірант, асистент кафедри \\ міжнародних економічних відносин та туризму, \\ Національний університет \\ «Полтавська політехніка імені Юрія Кондратюка» \\ ORCID: https://orcid.org/0000-0001-7068-8320
}

\section{ОСНОВНІ МЕТОДИКИ ТА ОСОБЛИВОСТІ СИСТЕМИ ПРОСУВАННЯ ОРГАНІЧНОЇ ПРОДУКЦІЇ}

Novytska Iryna

Yuriy Kondratyuk National University of Poltava

Сучасний стан розвитку соиіально-економічних процесів вимагає підвищення рівня продовольчої безпеки держави, особливо забезпечення населення високоякісними, екологічно безпечними продуктами харчування вітчизняного виробництва. У статті розглянуто поняття системи просування для виробників органічної продукиії; розкрито зміст основних компонентів цієї системи, таких як иілі, принципи, види, методи, функиії, організаційні структури управління, етапи і показники результатів просування продукиії. Відображено особливості системи просування органічної продукції. Запропоновано дві основні групи методик, призначені для виробників органічної продукції. Наведено короткий опис змісту ичих методик. Методики згруповані за основними етапами просування продукиії.

Ключові слова: органічне виробничтво, просування, продукиія, методи просування, держава.

\title{
BASIC METHODS AND FEATURES OF THE SYSTEM OF PROMOTION OF ORGANIC PRODUCTS
}

The current state of development of socio-economic processes requires increasing the level of food security of the state, especially providing the population with quality, environmentally friendly food products of domestic production. However, agricultural producers, trying to constantly increase production, use intensive technologies of agriculture based on chemicalization, which leads to significant soil degradation, violation of the ecological balance of agroecosystems, contamination of agri-food products with radionuclides, heavy metals, pesticides. Therefore, in Ukraine there is a strategic task - to increase the production of organic products to meet their own needs, while entering international food markets. It is established that in the framework of the implementation of modern marketing concepts for producers the attractiveness of organic production is growing. Ukraine lags far behind the developed countries in terms of organic consumption. Having identified the features of individual components of the complex of organic food sales and recommendations for their improvement in order to strengthen competitiveness in the market. Problems of developing scientific methods for promoting organic products in the marketing system of organic enterprises are insufficiently studied. In particular, this applies to methods of product promotion for organic producers, as well as the definition of the main elements of the product promotion system, which include goals, principles, types, methods, organizational structures, functions, stages and results of promotion of organic products. The article considers the concept of the system of promotion of organic producers; the content of the main components of this system, such as goals, principles, types, methods, functions, organizational management structures, stages and indicators of product promotion results are revealed. The peculiarities of the system of promotion of organic products are reflected. Two main groups of methods for producers of organic products are proposed. A brief description of the content of these techniques is given. Techniques grouped by the main stages of product promotion.

Keywords: organic production, promotion, products, promotion methods, state.

JEL classification: M31, L66, Q13

Постановка проблеми. Соціально-економічний розвиток України багато в чому залежить від стану і темпів зростання аграрної сфери, що становить основу реального сектору національної економіки. Поряд зі зростанням обсягів виробництва органічної продукції впровадження наукових методів організації, планування і контролю за ходом просування продукції стане умовою раціоналізації сукупності витрат і підвищення прибутку підприємства.

Зі збільшенням чисельності підприємств 3 ефективними системами просування продукції зросте сукупний прибуток цих підприємств за зниження витрат на просування продукції. Це в свою чергу приведе до зростання внутрішнього валового продукту, і з'являться передумови для підвищення якості життя населення.

Аналіз останніх досліджень і публікацій. Багато праць, пов'язаних з органічним виробництвом, присвя- чених створенню ринку органічних продуктів України, належать таким українським ученим, як Т.В. Боровик, I.М. Волкова, Р.С. Грабовський, Р.П. Дудяк, Т.О. Зайчук, Т.О. Чайка тощо. Зокрема, у [1, с. 25] проаналізовано особливості споживання органічної продукції в Україні і світі та розвитку каналів їі розподілу. Т.О. Чайкою досліджено ринок органічної продукції в Україні та світі [2, с. 235]. У праці Р.С. Грабовського досліджено ринок екологічно чистих продуктів харчування України, особливості його розвитку, визначено маркетингові інструменти, що визначають внутрішній попит на органічну продукцію.

Однак, проблеми розроблення наукових методів просування органічної продукції в системі маркетингу органічних підприємств вивчені недостатньо. Зокрема, це стосується методик просування продукції, призна- 
чених для органічних виробників, а також визначення основних елементів системи просування продукції, до яких належать цілі, принципи, види, методи, організаційні структури, функції, етапи і результати просування органічної продукції.

Мета статті полягає в дослідженні методів просування продукції в системі маркетингу та використання їх для просування органічної продукції від виробника до споживача.

Виклад основного матеріалу. 3 огляду на важливість ефективної організації просування органічної продукції як для підприємств-виробників продукції, iіi споживачів, так і загалом національної економіки в цій статті розглядається поняття системи просування органічної продукції, розкривається зміст основних елементів цієї системи, систематизуються методики просування продукції для виробників органічної продукції на основних етапах процесу просування.

Як відомо, під методом розуміється система засобів і прийомів того чи іншого виду діяльності. Щодо маркетингу загалом і просування продукції зокрема в літературі згадуються такі методи:

- економіко-фінансові методи - складання бюджету просування продукції, розрахунок оптимальної ціни продукції;

- соціологічні методи - анкетування і «панельні» обстеження переваг споживачів;

- психологічні методи - психологічні тести для виявлення мотивів споживчої поведінки і латентних переваг споживачів;

- методи антропології, що дають змогу на основі знань національних культур і рівня життя різних народів краще вивчити ринкове середовище для просування продукції;

- математичні методи - оптимізаційні моделі транспортування продукції, моделі управління товарними запасами, моделі аналізу і прогнозування попиту і споживання, моделі теорії масового обслуговування споживачів, вибір оптимального варіанту асортименту продукції та обгрунтування іiі ціни [11].

На наш погляд, ефективність просування продукції повинна визначатися на основі критерію максимізації прибутку підприємства від організації процесу просування продукції за мінімізації затрат на просування i залучення максимально можливого числа покупців.

Ми виділяємо декілька основних методик, призначених для виробників органічної продукції. У число методик і технологій входять:

1. Інформаційна система збору, обробки і передачі інформації, що стосується просування продукції, яка $\epsilon$ найважливішою частиною маркетингової системи головної організації. Інформаційна система включає в себе джерела вихідної інформації, способи контролю iii повноти та достовірності і способи іiі перетворення, накопичення і зберігання, алгоритми отримання вихідних результатів і порядок передачі іiі користувачам для прийняття управлінських рішень.

2. Інформаційна система взаємного обміну інформацією між виробником і споживачем. 3 інформаційною системою збору, обробки і передачі інформації повинна бути пов'язана система взаємного обміну інформацією. Основними видами даних, що передаються від виробника органічної продукції, $є$ різні маркетингові методики, розроблені головним центром, а також відо- мості, що стосуються координування, консультування та забезпечення діяльності окремих виробників.

3. Формування та організація діяльності команди креативних консультантів. Основне завдання креативних консультантів - генерування бізнес-ідей та стратегій просування продукції.

Основним методом генерування ідей із просування продукції є метод мозкового штурму. Він включає в себе такі етапи, як визначення проблеми, генерація й аналіз ідей, пошук можливостей для реалізації цих ідей.

Для узагальнення оцінок ідей експертів рекомендуємо застосовувати метод Делфі, що являє собою низку процедур, які спрямовані на формування групової думки експертів. Для цього методу характерні такі риси, як анонімність, зворотний зв'язок. Обробка результатів здійснюється за допомогою статистичних методів, i вони повідомляються експертам. Застосування методу Делфі дає змогу зменшити статистичні розбіжності індивідуальних оцінок, в яких найбільш правильно відображено думку кожного експерта. Процедура проведення опитувань у кілька турів з інформуванням експертів про результати попередніх етапів опитування i пропозиціями, що приводить до зменшення розкиду в індивідуальних відповідях і узагальнення індивідуальних думок експертів. Як характеристики положення i розкиду оцінок слід використовувати стійкі показники, такі як медіана і квартиль. Медіана є характеристикою групової відповіді, кращий інтервал квартилю - показником індивідуальних оцінок. Середні квартилі, розташовані зліва і праворуч від медіани, вважаються кращими характеристиками [9]. Для оцінки узгодженості думок експертів ми рекомендуємо також використовувати дисперсійний коефіцієнт конкордації [6].

4. Формування та актуалізація методик і технологій просування продукції. За головною організацією функції методологічного центру, заміщенням розробки, відбором і вдосконаленням методик і технологій просування продукції. Ці методики формуються у створеному за допомогою комп'ютерних технологій спеціалізованому банку даних. Цей банк включає в себе такі групи методик:

- проведення маркетингових досліджень ринку;

- планування просування продукції;

- організації доведення продукції від постачальника до споживача та контролю ефективності процесу просування продукції.

5. Проведення маркетингових досліджень ринку включають в себе у тому числі методики вибору i вивчення річних сегментів, виявлення потреби і рівня платоспроможності покупця, оцінки діяльності конкурентів і виробничих можливостей постачальників.

6. За допомогою методики планування просування продукції оцінюються основні параметри оптимального плану просування продукції, план поставки продукції від конкретного постачальника конкретному споживачеві, періоди поставки, оптимальні відстані від виробників до споживачів, плановані затрати часу, а також матеріальних і фінансових ресурсів, необхідних для просування продукції.

7. Організація просування продукції від виробника до споживача. Як відомо, процес просування продукції від виробника продукції до споживача включає в себе упаковку, навантаження і сепарацію продукції на транспорт, iї транспортування до пункту призначення і розвантаження продукції у вантажоодержувача. 
На практиці на етапі упаковки продукції рекомендуємо в міру можливості використовувати уніфіковану тару. Це буде сприяти підвищенню продуктивності праці, скороченню витрат на переробку одиниці маси вантажу, збереження продукції на всіх етапах іiі транспортування.

8. Формування системи контролю й оцінки ефективності процесу просування продукції. Система контролю ефективності процесу просування продукції включає в себе оцінку та аналіз комплексу показників ефективності процесів просування продукції. За допомогою маркетингового аудиту оцінюються рівень відповідності якості продукції стандартам та умовам договору; ступінь задоволеності споживача продукцією; тимчасовість поставки продукції згідно з договором; надійність постачальника та вантажовідправника; надійність споживача як платника й одержувача вантажів, а також транспортних коштів, за допомогою яких здійснюється доставка продукції; раціональність витрат на просування продукції; можливість виникнення проблем у процесі руху продукції від виробника до споживача.

Методики, призначені для виробників органічної продукції, ми пропонуємо згрупувати та розглянути за сімома етапами просування продукції.

Етап 1. Генерування бізнес-ідеї з просування продукції

Методики формування та організації діяльності команди креативних консультантів і генерування ідей iз просування продукції були описані вище для головного центру.

Етап 2. Дослідження ринку

У цю групу нами пропонується, крім методик дослідження власне ринку, також включити методики дослідження інфраструктури ринку, яка істотно впливає на просування продукції. Крім того, важливо використовувати методики просування продукції як матеріального об'єкта.

Вивчення товарної структури ринку. Методика включає в себе дослідження товарної структури ринку, якості товарів, які обертаються на ринку, а також аналіз видів і обсягів виробів, реалізованих на певних сегментах ринку. Застосування цієї методики дає змогу уникнути зайвих фінансових втрат під час просування продукції на нові ринки.

Аналіз потреб споживачів у продукції сприяє виділенню підприємством із великого числа потенційних споживачів певної групи, яка в подальшому стане безпосереднім споживачем продукції, пропонованої підприємством. За допомогою традиційних методів опитування та опитування за допомогою інтернет-технологій (шляхом голосування й оцінювання продукції) можна виділити товари, що користуються найбільшим попитом.

Аналіз конкурентів. За допомогою SWOT-аналізу визначається перелік потенційних конкурентів, їхній поточний стан на ринку, фінансові можливості, можливі стратегії і цілі, а також сильні і слабкі сторони конкурентів.

Аналіз цінової політики дає змогу підприємству на основі проведення досліджень і аналізу ринкових цін конкурентів встановлювати ціни на свою продукцію і змінювати їх залежно від ситуації на ринку, орієнтуючись при цьому на дії з боку конкурентів. Оцінка ємності ринку дає змогу визначити обсяг проданої продукції за певний період часу, як правило, за рік. Смність ринку можна розрахувати за формулою:

$$
\mathrm{V}=\Pi+\mathrm{I}-\mathrm{E}+(\mathrm{Biн}-\mathrm{O \kappa})+(3 \mathrm{H}+3 \kappa),
$$

де $3 \mathrm{H}-$ обсяг запасів на початок періоду;

Зк - обсяг запасів на кінець періоду;

Він - обсяг залишків на початок періоду;

Ок - обсяг залишків на кінець періоду;

I - імпорт;

Е - експорт;

П - виробництво товарів і послуг.

Складання карти ринку, яка відображає всі зв'язки між основними учасниками ринку (виробниками, посередниками, продавцями і споживачами) i те, як вони впливають на стан ринку. Створення карти ринку означає отримання повної інформації про те, хто на ринку відіграє помітну роль. Вивчення кон'юнктури ринку дає змогу визначити обстановку, що виникла на ринку або на певному його сегменті. Для визначення стану кон'юнктури ринку використовуються показники попиту та пропозиції на товари та цінові показники. За допомогою індексу Герфіндаля-Гіршмана оцінюється стан конкуренції на ринку. Цей індекс являє собою суму квадратів часток усіх фірм, що діють на ринку. Індекс приймає значення від нуля (в разі ідеальної конкуренції, коли на ринку нескінченно багато продавців, кожен 3 яких контролює незначну частку ринку) до одиниці (коли на ринку діє тільки одна фірма, яка виробляє $10 \%$ продукціï). Чим більше значення індексу, тим вища концентрація продавців на ринку. Основна перевага індексу полягає в чуйному реагуванні на перерозподіл часток між фірмами, що діють на ринку.

Аналіз просування образу продукції полягає у вивченні просування i безпосередньо образів продукції підприємств-конкурентів із метою формування власного, має свою специфіку, спосіб, характерний для сегменту ринку, на якому знаходиться підприємство. Підприємству також слід періодично вивчати ринок i безпосередньо враховувати зміни, що відбуваються на ньому, з метою внесення деяких коригувань в образ продукції. Аналіз інфраструктури ринку включає в себе аналіз об'єктів інфраструктури ринку, що мають істотний вплив на процес просування продукції. До цих об'єктів слід віднести комплекс галузей господарства, які обслуговують виробництво продукції, а саме будівництво доріг, каналів, портів, мостів, аеродромів та складів, а також транспорт, зв'язок тощо. Аналіз ринкової інфраструктури повинен проводитися $з$ позиції того, якою мірою вона сприяє ефективному просуванню продукції.

Аналіз якості зберігання готової продукції визначає умови сприятливого впливу на процес зберігання продукції, до яких в тому числі відносяться придатність складських приміщень для зберігання продукції, що гарантується терміном зберігання продукції на складі.

Аналіз якості каналів транспортування. Ця методика дає змогу виявити найбільш підходящі канали транспортування і безпосередньо види транспорту для ефективного просування продукції.

Аналіз якості роботи комунікаційних каналів між учасниками процесу просування полягає в оцінці якості та ефективності використання технічних і технологічних засобів, що сприяють своєчасній передачі та забезпеченню інформацією учасників процесу просування продукції. 
Етап 3. Планування просування продукції

Для цього етапу потрібно розробити комплекс методик, призначених для аналізу якості планування процесу просування продукції, в тому числі сформувати плани поставки продукції постачальником споживачеві на основі задоволення його потреб за обсягами і строків ії виплати, поставки конкретних видів продукції, а також мінімізації транспортних витрат.

Планування вибору ринкового сегмента полягає у визначенні найбільш підходящого сегмента і його розташування для подальшого просування продукції i максимізації прибутку від продажів.

Планування формування попиту i стимулювання збуту сприяє ефективній реалізації продукції за допомогою розподілу продукції в ринковому просторі, цінової політики та реклами, визначення найбільш ефективних каналів розподілу інформації про продукцію.

Планування процесу просування продукції полягає у формуванні планів, на основі яких буде організовувати процес просування.

Етап 4. Просування способу продукції

Методики цього етапу спрямовані на організацію просування образу продукції з метою інформування споживачів. Це насамперед реклама образу продукції, налагодження зв'язків із громадськістю, формування іміджу фірми, брендинг, проведення виставок і ярмарків тощо [10].

Реклама продукції. Реклама повинна виконувати такі функції, як інформування, переконання, навіювання і нейролінгвістичне програмування, що сприяють ефективному просуванню образу продукції. Основна психологічна функція інформування полягає в забезпеченні запам'ятовування образу продукції. Суть переконання як найважливішого способу психологічного рекламного впливу полягає в тому, що продавець повинен переконати покупця в цінності товару, що рекламується, а також у необхідності його придбати. Навіювання являє собою процес впливу на психіку людини, пов'язаний зі зміною підсвідомості та критичності під час сприйняття образу продукції. Завдання спонукання полягає у виникненні негайної реакції споживача на рекламу способу продукції, тобто його «спонукання» купити товар. Сутність нейролінгвістичного програмування полягає у підсвідомому прагненні конкретної людини створювати смислові конструкції, які відповідають ії очікуванням і світосприйняттю, або до так званого осмислення.

Налагодження зв'язку з громадськістю із просування образу продукції слід розглядати як систему, що складається 3 таких компонентів, як: зв'язок із засобами масової інформації, PR за допомогою друкованої продукції, участь представників підприємства у конференціях громадських організацій, організація підприємством заходів дієвого характеру.

Формування іміджу підприємства для ефективного просування продукції полягає в формуванні таких характеристик, як незмінність у сприйнятті споживачів, оригінальність, орієнтація на визначенні групи споживачів.

Брендинг полягає в організації діяльності зі створення довгострокової переваги товару, в тому числі розроблення таких компонентів, як товарний знак, товарна упаковка і рекламні звернення, що спільно діють на споживача [10].

Організація ярмарків і виставок з метою ефективного просування продукції. Вибір території проведення ярмарків і виставок залежить від смаків та вподобань споживачів у конкретному регіоні, оскільки саме від них залежить ефективність просування образу продукції. Попередньо проводяться опитувальні дослідження, що показують доцільність проведення виставки у вибраному регіоні. Далі складається бюджет виставки й оцінюється ефективність її організації.

Етап. 5. Планування доведення продукції від виробника до споживача

На цьому етапі повинні застосовуватися методики планування вибору товаропровідного каналу, планування процесу доведення продукції і планування післяпродажного обслуговування. Планування вибору товаропровідного каналу (маршрут) полягає у визначенні переліку найбільш вигідних каналів, що сприяють ефективному просуванню продукції від виробника до покупця з мінімальними втратами часу і фінансовими витратами. У результаті аналізу вибирається найбільш оптимальний варіант товаропровідного каналу.

Планування процесу просування продукції полягає у формуванні планів поставки продукції від постачальника споживачам.

Планування післяпродажного обслуговування полягає у визначенні термінів поставки продукції споживачеві, гарантійних періодів і умов гарантій, а також засобів сервісного обслуговування продукції.

Етап 6. Просування продукції від виробника до споживача

Організація процесу просування продукції від виробника до споживача спрямована на виконання умов укладеного договору на поставку між споживачем і постачальником, насамперед умов якості, термінів і обсягів поставок продукції. Крім того, організація просування продукції передбачає своєчасне виявлення й усунення проблем і форс-мажорних обставин, що виникають у процесі просування продукції.

Етап 7. Контроль за ефективністю просування продукції

Контроль і регулювання доведення продукції. Для контролю за просуванням продукції необхідно організувати спеціальні групи в кожній бізнес-одиниці, основною функцією яких є виявлення та рішення виникаючих проблем, що стосуються якості продукції, обсягів і термінів іiі поставки, на всіх раніше розглянутих етапах. Контроль зовнішнього середовища підприємства спрямований на виявлення змін, що відбуваються на ринку, з метою зниження їхнього негативного впливу на процес просування продукції.

Висновки. Організація системи просування органічної продукції є одним із найважливіших факторів соціально-економічного розвитку національної економіки.

Основною метою виробників органічної продукції є виробництво продукції і продаж іiі споживачам відповідно до їхнього платоспроможного попиту. Щоб досягти зазначеної мети, виробникам органічної продукції необхідно побудувати ефективну систему просування продукції споживачам.

Система просування органічної продукції заснована на вивченні різних сегментів ринку під час взаємодії головної організації і бізнес-одиниць. Відповідно для маркетингових підрозділів головної організації i бізнес-одиниць повинні бути розроблені методики просування органічної продукції, що охоплюють усі ланки цього процесу. 


\section{Список використаних джерел:}

1. Боровик Т.В. Маркетингове забезпечення ринку органічної продукції в умовах трансформації економіки. Наукові праці Полтавської державної аграрної академії. 2012. Вип. 4. Т. 1. С. 24-29.

2. Чайка Т.О. Передумови розвитку ринку органічної продукції в Україні . Маркетинг і менеджмент інновацій. 2011 . № 4. T. I. C. $233-240$.

3. Волкова І.М. Дослідження поведінки споживачів на ринку органічної продукції. Збірник наукових праць Таврійського державного агротехнологічного університету (економічні науки). 2013. № 1(2). С. 47-53.

4. Зайчук Т. О. Вітчизняний ринок екологічно чистих продуктів харчування та шляхи його розвитку. Економіка і прогнозування. 2009. № 4. С. 114-125.

5. Грабовський Р.С. Конкурентоспроможність органічної продукції на продовольчому ринку України. Науковий вісник НЛТУ України. 2012. Вип. 22.9. С. 184-188.

6. Маслак О. Ринок органіки в Україні: стан та перспективи. Агробізнес сьогодні : веб-сайт. URL: http:/www.agro-business.com.ua/ ekonomichnyi-gektar/806-rynok-organiky-v-ukraiini-stan-ta-perspektyvy.html (дата звернення: 20.09.2020).

7. Лупенко Ю.О. Формування попиту та пропозиції на ринку органічної продукції. Органічне виробництво і продовольча безпека: Матеріали Міжнародної науково-практичної конференції (Житомир, 19 квітня 2013 р.). Житомир : «Полісся», 2013. C. 3-9.

8. Гаваза Є.В. Доступність органічної продукції як індикатор забезпечення населення екологічно безпечними продуктами харчування. Збалансоване природокористування. 2014. № 2. С. 142-148.

9. Перелік роздрібних точок та мереж маркетів із продажу органічних i натуральних продуктів : веб-сайт. URL: http://www.organicstandard.com.ua/files/important_information/ua/\%D0\%9E\%D0\%A1_\%D0\%BC\%D0\%B0\%D0\%B3\%D0\% B0\%D0\%B7\%D0\%B8\%D0\%BD\%D0\%B8_\%D1\%83\%D0\%BA\%D1\%80.pdf

10. Іванова Л.С. Брейдінг як спосіб просування органічної. Економіка та держава. 2015. № 10. С. $49-52$.

11. Орленко О.В. Ефективність інструментів просування круп'яної органічної продукції на вітчизняні та європейські ринки в умовах глобалізації. Бізнес-навігатор. 2015. № 1(36). С. 53-59.

\section{References:}

1. Borovyk T.V. (2012) Marketing providing of organic products in the economic transformation [Marketing support of the market of organic products in the conditions of economic transformation]. Naukovi pratsi Poltavs'koi derzhavnoi ahrarnoi akadem, vol. 4, pp. 24-29.

2. Chajka T.O. (2011) Preconditions for development of the market of organic products in Ukraine [Prerequisites for the development of the organic products market in Ukraine]. Marketynh $i$ menedzhment innovatsi, vol. 4, pp. 233-240.

3. Volkova I.M. (2013) The study of consumer behavior in the organic products market [Research of consumer behavior in the market of organic products]. Zbirnyk naukovykh prats' Tavrijs'koho derzhavnoho ahrotekhnolohichnoho universytetu (ekonomichni nauky), vol. 1(2), pp. 47-53.

4. Zajchuk T.O. (2009) The domestic market of organic foods and ways of its development [Domestic market of environmentally friendly products nutrition and ways of its developmen]. Ekonomika i prohnozuvannia, vol. 4, pp. 114-125.

5. Hrabovs'kyj R.S. and Dudiak R.P. (2012) Competitiveness organic products in food markets Ukraine [Competitiveness of organic products in the food market of Ukraine]. Naukovyj visnyk NLTU Ukrain, vol. 22.9, pp. 184-188.

6. Maslak O. (2014) Organic market in Ukraine: state and prospects [The organic market in Ukraine: status and prospects]. Ahrobiznes s'ohodni. Available at: http://www.agro-business.com.ua/ekonomichnyi-gektar/806-rynok-organiky-v-ukraiini-stan-ta-perspektyvy.html (accessed 20 September 2020).

7. Lupenko Yu.O. (2013) Formation of demand and supply of organic products [Formation of supply and demand in the market of organic products]. Materialy Mizhnarodnoi naukovo-praktychnoi konferentsii [International scientific-practical conference]. Orhanichne vyrobnytstvo i prodovol'cha bezpeka [Organic production and food safety], Zhytomyr, Ukraine, 19.04.2013, pp. 3-9.

8. Havaza Ye.V. (2014) The availability of organic products as an indicator of providing the population with ecologically safe food [Availability of organic products as an indicator of providing the population with ecologically safe food]. Zbalansovane pryrodokorystuvannia, vol. 2, pp. 142-148.

9. The list of retail outlets and chains of supermarkets selling organic and natural products [ List of retail outlets and supermarket chains selling organic and natural products]. Available at: http://www.organicstandard.com.ua/files/ important_information $/ \mathrm{ua} / \% \mathrm{D} 0 \% 9 \mathrm{E} \% \mathrm{D} 0 \% \mathrm{~A} 1 \_\% \mathrm{D} 0 \% \mathrm{BC} \% \mathrm{D} 0 \% \mathrm{~B} 0 \% \mathrm{D} 0 \% \mathrm{~B} 3 \% \mathrm{D} 0 \% \mathrm{~B} 0 \% \mathrm{D} 0 \% \mathrm{~B} 7 \% \mathrm{D} 0 \% \mathrm{~B} 8 \% \mathrm{D} 0 \% \mathrm{~B}-$ D\%D0\%B8 \%D1\%83\%D0\%BA\%D1\%80.pdf (accessed 25 September 2020).

10. Ivanova L.S. (2015) Branding as a mean of promoting organic products [Braiding as a way to promote organic]. Ekonomika ta derzhava, vol. 10, pp. 49-52.

11. Orlenko O.V. (2015) The effectiveness of grinding tools to promote organic products in the domestic and European markets in the context of globalization [Effectiveness of tools for promoting organic cereals in domestic and European markets in the context of globalization]. Biznes-navihator, vol. 1(36), pp. 53-59. 